\title{
New Data on the Basement of Franz Josef Land, Arctic Region
}

\author{
V. B. Ershova ${ }^{a, c, *}$, A. V. Prokopiev ${ }^{b}$, N. N. Sobolev ${ }^{c}$, E. O. Petrov ${ }^{c}$, A. K. Khudoley ${ }^{a, b}$, \\ J. I. Faleide ${ }^{d}$, C. Gaina ${ }^{d}$, and R. V. Belyakova ${ }^{a}$ \\ ${ }^{a}$ Faculty of Geology, St. Petersburg State University, Universitetskaya nab. 7, St. Petersburg, 199034 Russia \\ ${ }^{b}$ Diamond and Precious Metal Geology Institute, Siberian Branch of the Russian Academy of Sciences, \\ prosp. Lenina 39, Yakutsk, 677007 Russia \\ ${ }^{c}$ Karpinsky All-Russia Geological Research Institute, Srednii pr. 74, St. Petersburg, 199106 Russia \\ ${ }^{d}$ Centre for Earth Evolution and Dynamics, CEED, Department of Geosciences, University of Oslo, \\ Blindern 1028, Oslo, 0315 Norway \\ *e-mail: v.ershova@spbu.ru \\ Received May 19, 2016
}

\begin{abstract}
We have studied pebbles of igneous rocks from the Lower Jurassic sedimentary succession of Hall Island, Franz Josef Land. Pebbles are represented by felsic intrusive and extrusive rocks, often cataclased and greisenized. The $\mathrm{U}-\mathrm{Pb}$ age of crystallization for zircons of the studied samples yielded the Latest DevonianEarly Carboniferous and Early-Middle Permian ages. In addition, the studied zircons demonstrate a broad scatter of ages, from Middle Paleozoic to Mesozoic, suggesting repeated thermal reworking and metamorphism of granites. It is shown that coeval Late Paleozoic magmatism indicates the similarity of the geological evolution of the northern Barents Sea and the Severnaya Zemlya archipelago.
\end{abstract}

Keywords: Arctic region, Franz Josef Land, Mesozoic, provenance area, isotope geology

DOI: $10.1134 / \mathrm{S} 0016852117020030$

\section{INTRODUCTION}

Franz Josef Land (FJL) is located in the Arctic Ocean and is one of the key regions for understanding the geology of the northern margin of the sedimentary basin of the Barents Sea and the entire western Arctic. Within the limits of this archipelago, sedimentary complexes referring to the Triassic, Jurassic, and Cretaceous are exposed and almost universally overlapped by Early Cretaceous flood basalts [1-3]. The basement of the northern Barents Sea basin has only been studied by seismic surveys, whereas its composition, structure, and age remain disputable. Within the limits of FJL, Paleozoic and more ancient rocks have been recovered at the Nagurskaya borehole on the island of Alexandra Land [1-3]. Here, Lower Triassic argillites are underlain with a considerable angular unconformity by Upper Carboniferous bioclastic limestones $83 \mathrm{~m}$ thick and by Lower Carboniferous mostly quartz coal-bearing sandstones and siltstones $160 \mathrm{~m}$ thick [5]. Gently occurring Carboniferous deposits overlap intensively deformed metamorphic rocks of the basement (Nagurskaya Series), occurring at angles of $20^{\circ}-$ $75^{\circ}$, with a sharp angular unconformity. The metamorphic complex can be subdivided into two units separated by a mafic intrusion $400 \mathrm{~m}$ thick: the upper unit (depth interval $1895-2910 \mathrm{~m}$ ) is represented by quartzites; the lower unit (depth interval 2910$3204 \mathrm{~m}$ ) is composed of phyllites and quartz-sericite schists [1]. The thickness of the recovered part of the Nagurskaya Series is $1309 \mathrm{~m}$. These metamorphic rocks were referred as Late Proterozoic [5]. Isotope datings obtained from phyllites and sandstones of the metamorphic complex [7,10,18] confine the age of these rocks as Middle-Late Neoproterozoic. The ${ }^{40} \mathrm{Ar}-{ }^{39} \mathrm{Ar}$ dating of detrital micas has yielded the broad scatter of ages (360-665 Ma), indicating that repeated thermal events took place during Late Caledonian time [18]. In the absence of other boreholes penetrating the basement in both FJL itself and in the surrounding offshore area, we can consider pebbles of different composition from the several levels of Mesozoic succession [1-3], to be an indirect data source for deciphering the age of the basement in the sedimentary basin of the northern Barents Sea.

We attempted to infer age of the northern Barents Sea basement based on $\mathrm{U}-\mathrm{Pb}$ dating of zircons from pebbles of igneous rocks collected from Lower Jurassic deposits of Hall Island, southeastern FJL.

\section{COMPOSITION OF THE LOWER JURASSIC SECTION OF HALL ISLAND AND SAMPLING POINTS}

Lower Jurassic deposits were studied in the Cape Tegethoff (Hall Island). There, the Tegethoff Formation is represented by predominantly sands with a vis- 

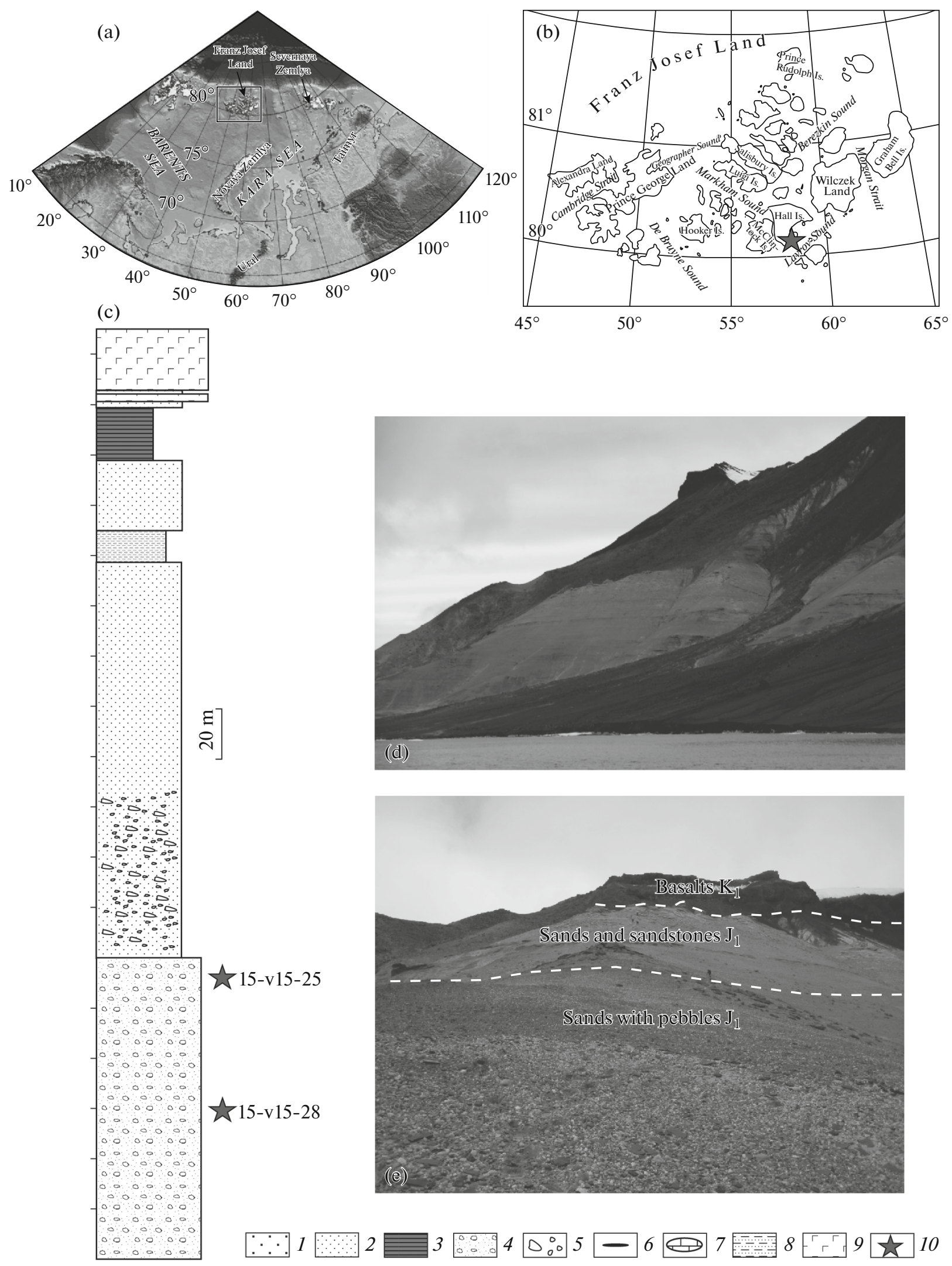

$15-\mathrm{v} 15-25$
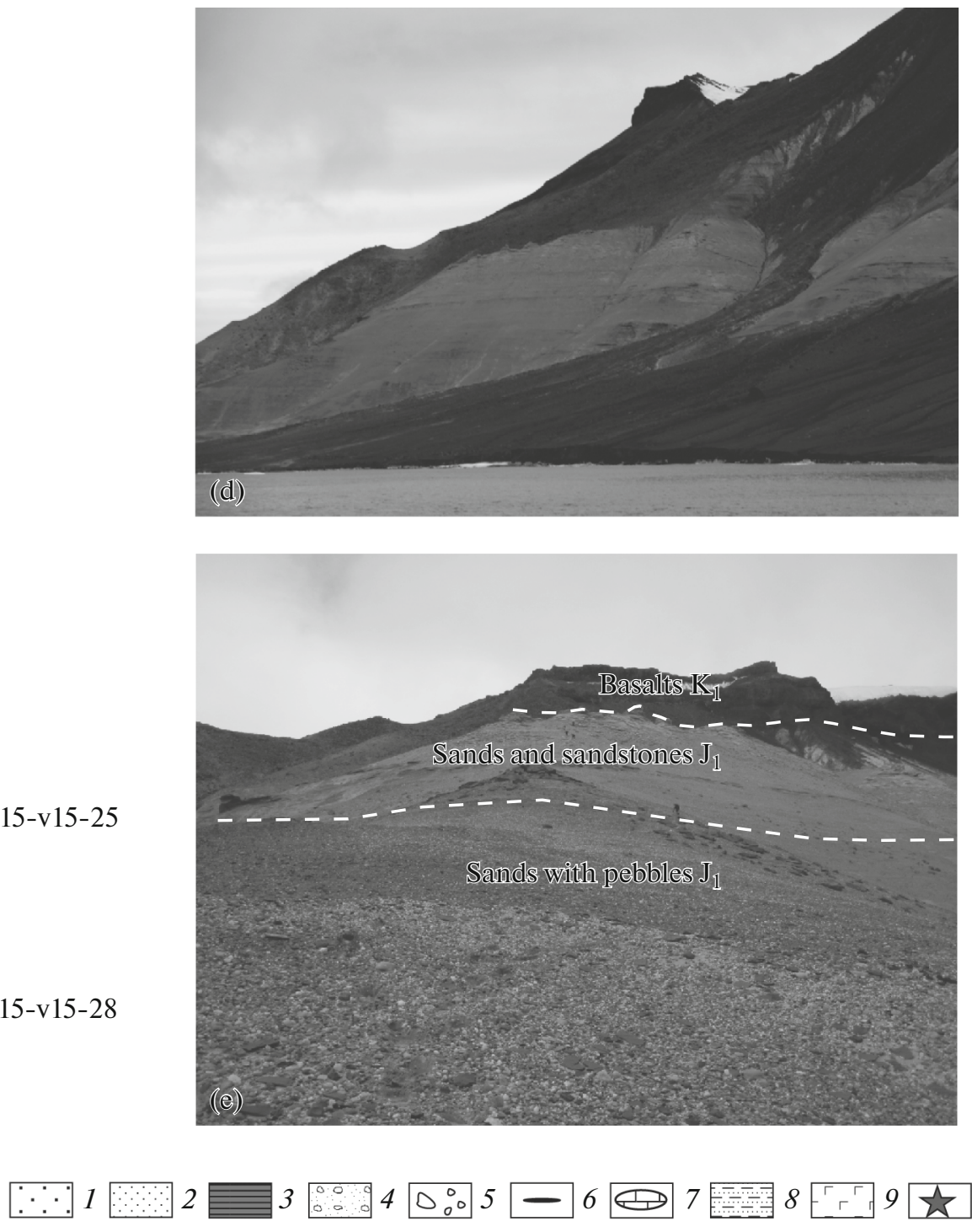

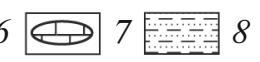
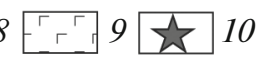

Fig. 1. Location of study area and stratigraphic location of studied samples. Panels (a) and (b) show location of study area; (c) stratigraphic column of Lower Jurassic deposits (Tegethoff Formation) of Cape Tegethoff, Hall Island, FJL; (d) general view of exposure; (e) polymictic pebbles in sandy matrix in lower Tegethoff Formation. (1) Medium-grained sands and sandstones; (2) finegrained sands and sandstones; (3) clays and argillites; (4) sands with pebbles; (5) scattered pebbles; (6) coals; (7) carbonate concretions; (8) thin interbedding of clays and sands; (9) basalts; (10) locations and numbers of dated samples. 
ible thickness of $\sim 370 \mathrm{~m}$ (Fig. 1). On the basis of scarce fossil findings and palynological data, the age of this formation spans from the Pliensbachian to the Early Toarcian [3]. The lower part of this section is represented by thick (about $120 \mathrm{~m}$ ) units of pebbles with sandy matrix. Composition of pebbles is quite varied: granites, felsic extrusive rocks, limestones, quartzites, and argillites. Upsection, sands and weakly cemented sandstones occur (total thickness $\sim 200 \mathrm{~m}$ ): fine- to medium-grained, gray and yellowish (rarely, dark reddish brown) in color, with multidirectional cross bedding. In the lower part of the unit, sands contain floating pebbles of mainly carbonate composition. Interbeds of dark gray and gray thinly bedded siltstones and clays appear in the upper part of the section (their thickness is no more than 1.5-2 m). The uppermost part of the formation is a mostly clayey unit about $23 \mathrm{~m}$ thick. Sedimentary rocks are overlapped by Cretaceous tuff sandstones 10-12 m thick and columnar basalts. The rocks gently (at up to $10^{\circ}$ ) dip WNW.

Samples for $\mathrm{U}-\mathrm{Pb}$ geochronology (15-v15-25 and 15-v15-28) were collected from the middle and lower parts of the unit composed of pebbles with sandy matrix in the lower part of the Tegethoff Formation.

\section{U-PB DATING RESULTS}

The zircon monofraction was extracted at the Institute of Precambrian Geology and Geochronology, Russian Academy of Sciences (St. Petersburg), by the standard scheme: shattering, sieving, the $<0.25 \mathrm{~mm}$ fraction flowed through a centrifugal concentrator, and the obtained heavy fraction was treated by an electromagnet. The concentrate was ultimately treated in a heavy liquid. $\mathrm{U}-\mathrm{Pb}$ dating of zircons was performed on a SHRIMP-II ion microprobe, at the Center for Isotope Research, Karpinsky All-Russia Geological Research Institute (St. Petersburg). The collected zircon grains were planted into an epoxy resin with grains of TEMORA and a 91500 zircon standard and then ground off and polished to approximately half their thicknesses. To select the sampling points for dating on the surfaces of grains, we used optical (in transmitted and reflected light) and cathodoluminescence images showing the inner structure and zonality of zircon grains (Fig. 2).

$\mathrm{U}-\mathrm{Pb}$ ratios were determined with SHRIMP-II by the technique described in [19]. The intensity of the initial beam of molecular negatively charged oxygen ions was $\sim 2.5$ to $4 \mathrm{nA}$; spot size, $\sim 15 \times 10 \mu \mathrm{m}$.

The data were processed by SQUID software [16]. $\mathrm{U}-\mathrm{Pb}$ ratios were normalized to the value 0.0668 assigned to the TEMORA standard zircon, which corresponds to the age of the respective zircon (416.75 Ma) [11]. Errors in single analyses (ratios and ages) are given at one sigma level; errors of calculated concordant ages, at two sigma levels. When constructing the concordia plots, the ISOPLOT software was used [17]. The results are given in the table.

\section{Sample 15-v15-28/1}

Pebble consist of coarse-grained, leucocratic, cataclased plagiogranite (Fig. 3a). Quartz grains are occasionally fractured; plagioclases demonstrate bended twins. Zircon crystals and their fragments are light brown and brown, transparent and semitransparent, idiomorphic and subidiomorphic prismatic. Based on the dating results eight zircon grains yielded a concordant age of $363 \pm 1.1 \mathrm{Ma}$ (Fig. 4a). The two oldest grains (2.1 and 3.1) were excluded from the following interpretation (see table).

\section{Sample 15-v15-28/2}

Pebble of medium to coarse-grained, cataclased, two-mica and two-feldspar granite (Fig. 3b). Feldspars are represented by microcline and oligoclase. Quartz grains are cataclased and fractured. Zircons are yellow and brown in color and transparent. Crystal shapes vary from idiomorphic and subidiomorphic prismatic to oval and rounded; nevertheless, there is no correlation between grain shape and its age. Dated zircons do not form age groups, but are distributed irregularly along the concordia, with small ${ }^{206} \mathrm{~Pb} /{ }^{238} \mathrm{U}$ age clusters ranging from Middle Devonian (399.6 \pm $2.6 \mathrm{Ma})$ to Early Permian $(273.7 \pm 2.0 \mathrm{Ma})$ and Early Mesozoic $(206.2 \pm 2.9$ to $153.9 \pm 1.4 \mathrm{Ma})$. The absence of more significant clusters prevents determination of the age of rocks (Fig. 4b; table).

\section{Sample 15-v15-28/4}

Pebble of rhyolite porphyry. Matrix is composed of felsite; porphyry impregnations are represented by quartz, oligoclase, and orthoclase (Fig. 3c), with occasional chloritized biotite. Zircons are colorless and transparent, represented by idiomorphic prismatic crystals and their fragments. Based on the dating results for nine zircon grains, we obtained a concordant age of $328.4 \pm 1.1 \mathrm{Ma}$ (Fig. 4c). There was the single grain (4.1, see table) with ${ }^{206} \mathrm{~Pb} /{ }^{238} \mathrm{U}$ age of $943.4 \pm 6.2 \mathrm{Ma}$; however, since this is the only Neoproterozoic in age grain out of 51 dated zircons, that could not be used to reconstruct provenance area.

\section{Sample 15-v15-28/5}

Pebbles of medium- to coarse-grained, mostly plagioclase leucogranite with micropegmatite texture. Micropegmateite aggregates are represented by quartz and plagioclase (Fig. 3d). Yellowish zircons are transparent and semitransparent, represented by idiomorphic and subidiomorphic prismatic crystals and their fragments. Based on the $\mathrm{U}-\mathrm{Pb}$ dating results for all 
Sample no. $15 \mathrm{v} 15-28 / 1$

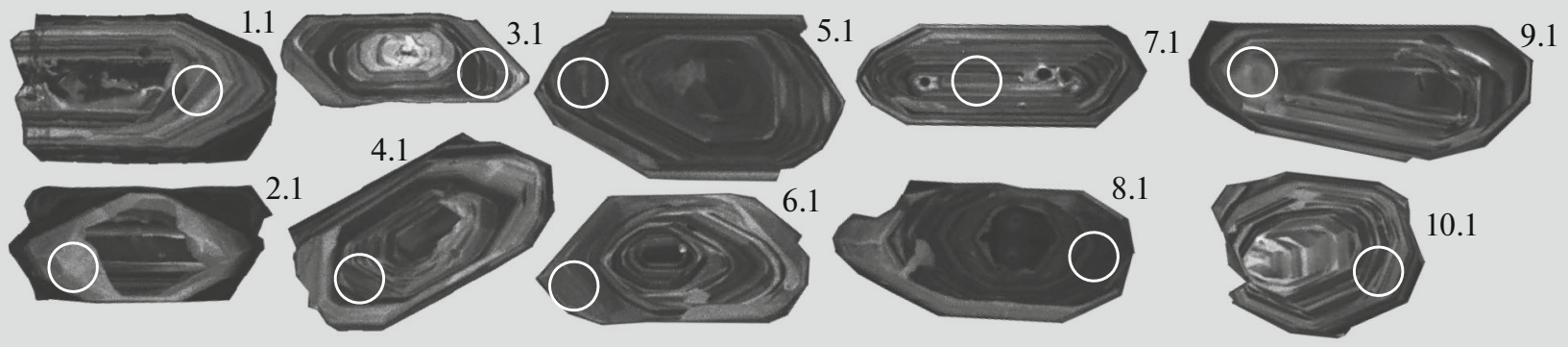

Sample no. 15-v15-28/2

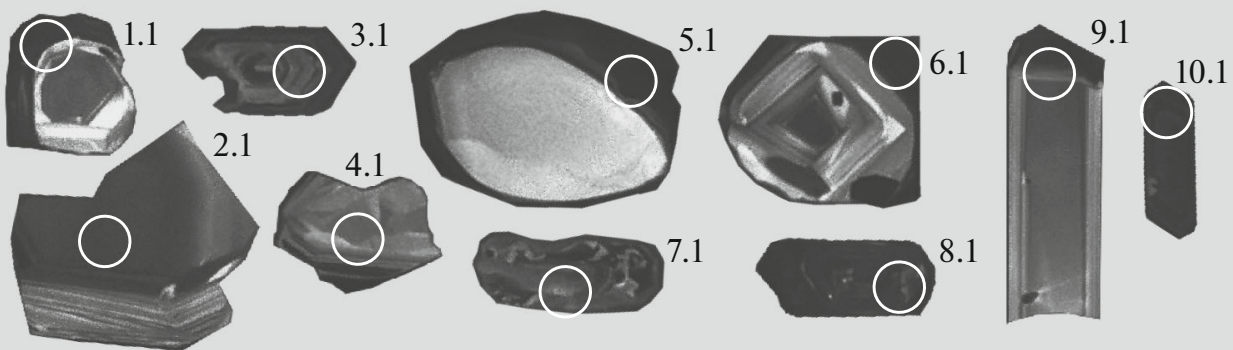

Sample no. $15-\mathrm{v} 15-28 / 4$

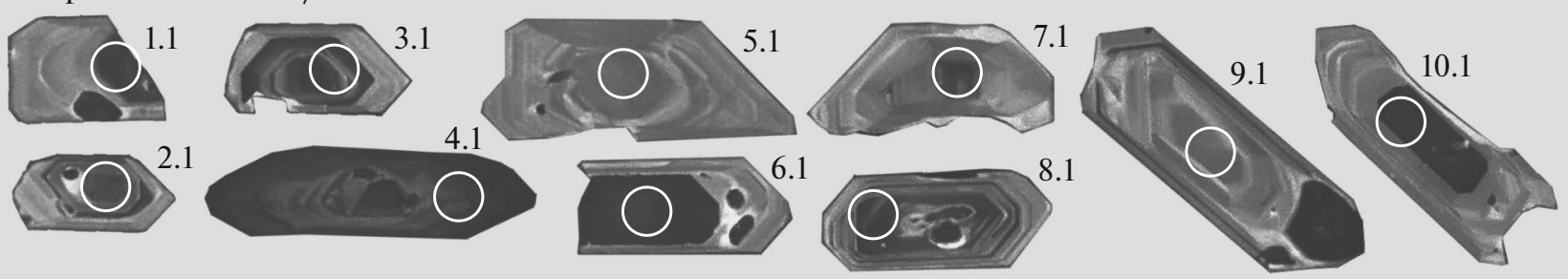

Sample no. $15-\mathrm{v} 15-28 / 5$

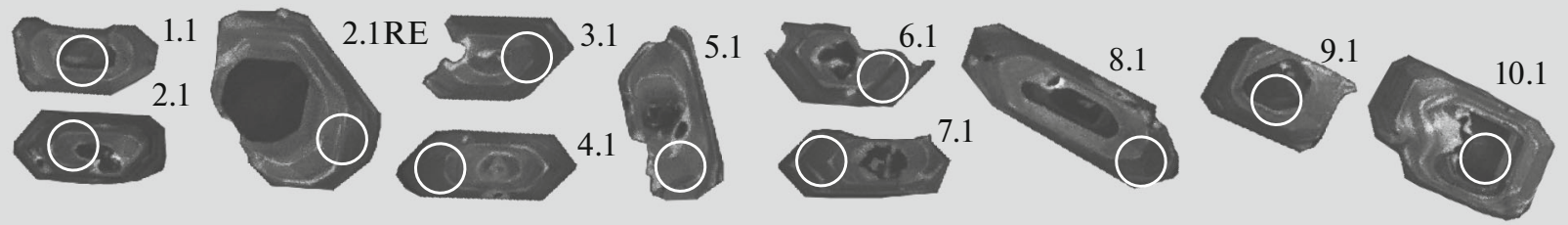

Sample no. $15 v 15-25 / 2$

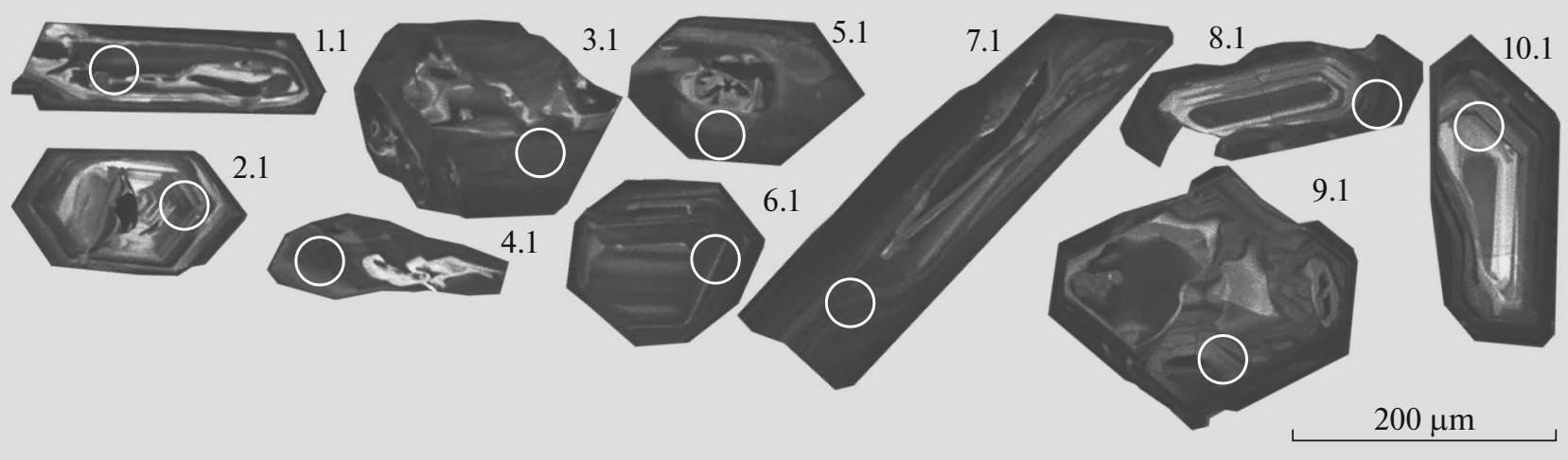

Fig. 2. Microimages of zircons from the studied samples in cathodoluminescence. 

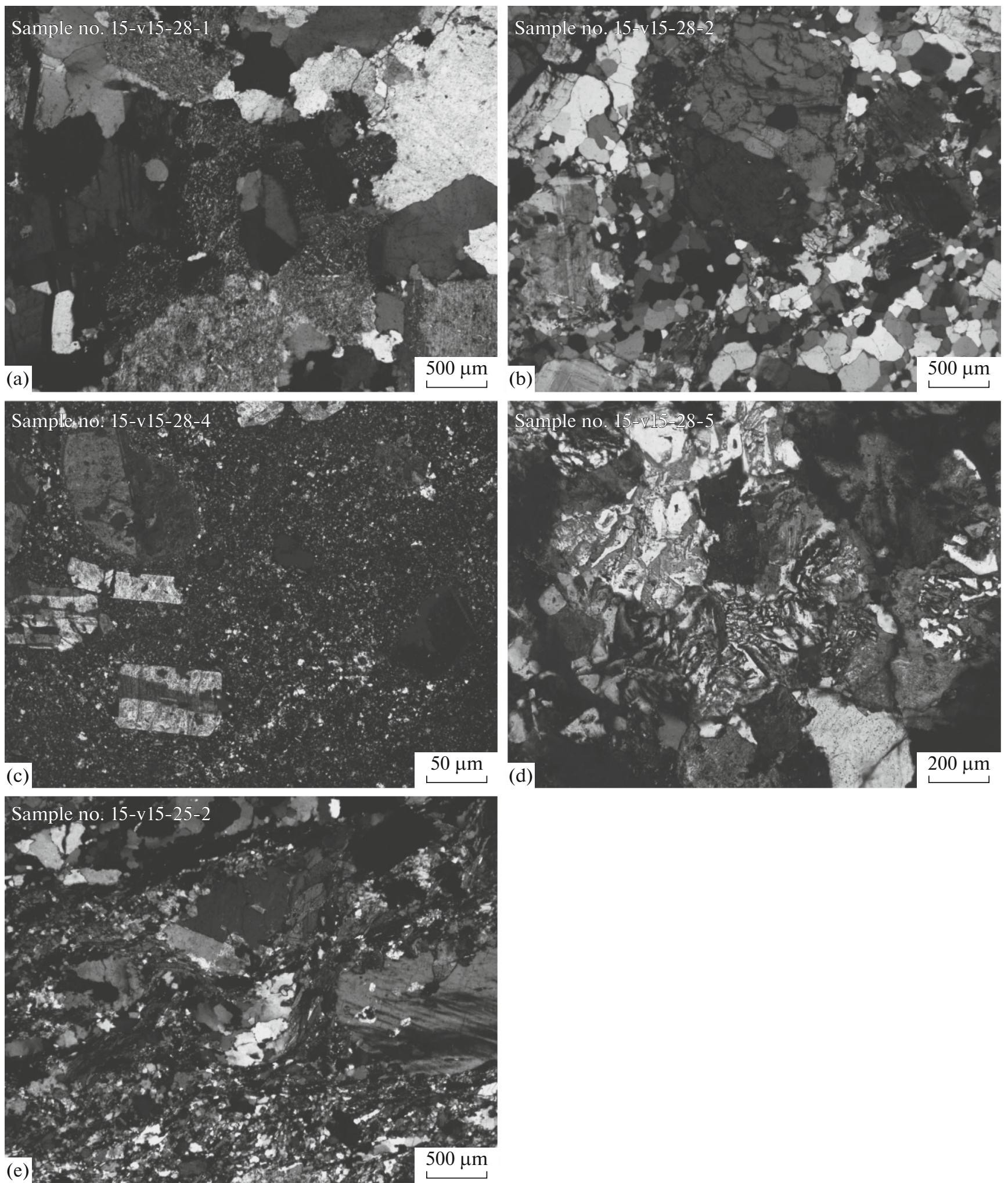

Fig. 3. Microphotographs of thin sections of dated igneous rocks in polarized light: (a) coarse-grained plagiogranite (sample no. 15-v15-28/1); (b) cataclased medium-grained granite (15-v15-28/2); (c) rhyolite porphyry (15-v15-28/4); (d) fine- to medium-grained leucogranite (15-v15-28/5); (e) porphyraceous medium- to coarse-grained cataclased granite (15-v15-25/2). 


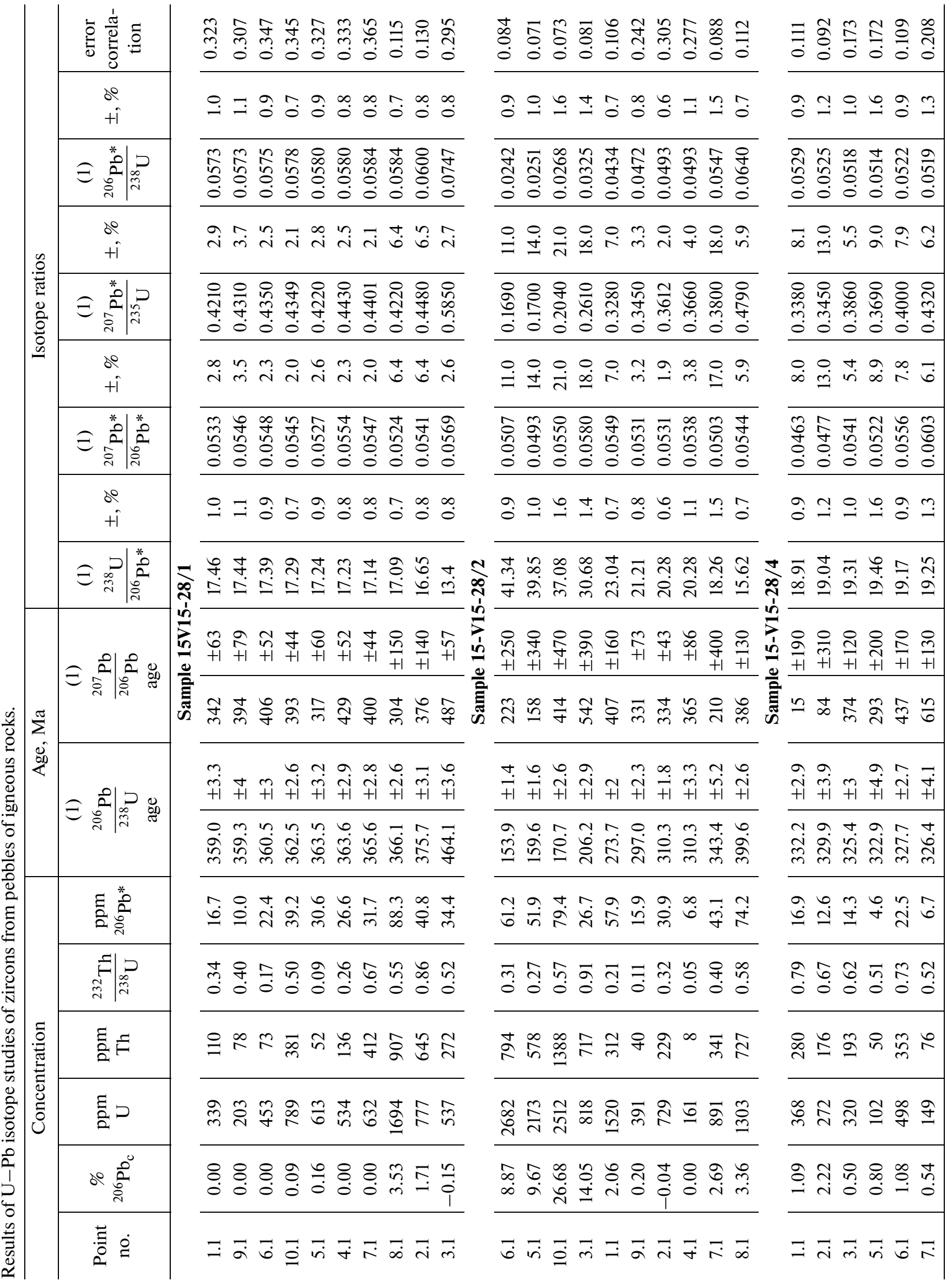




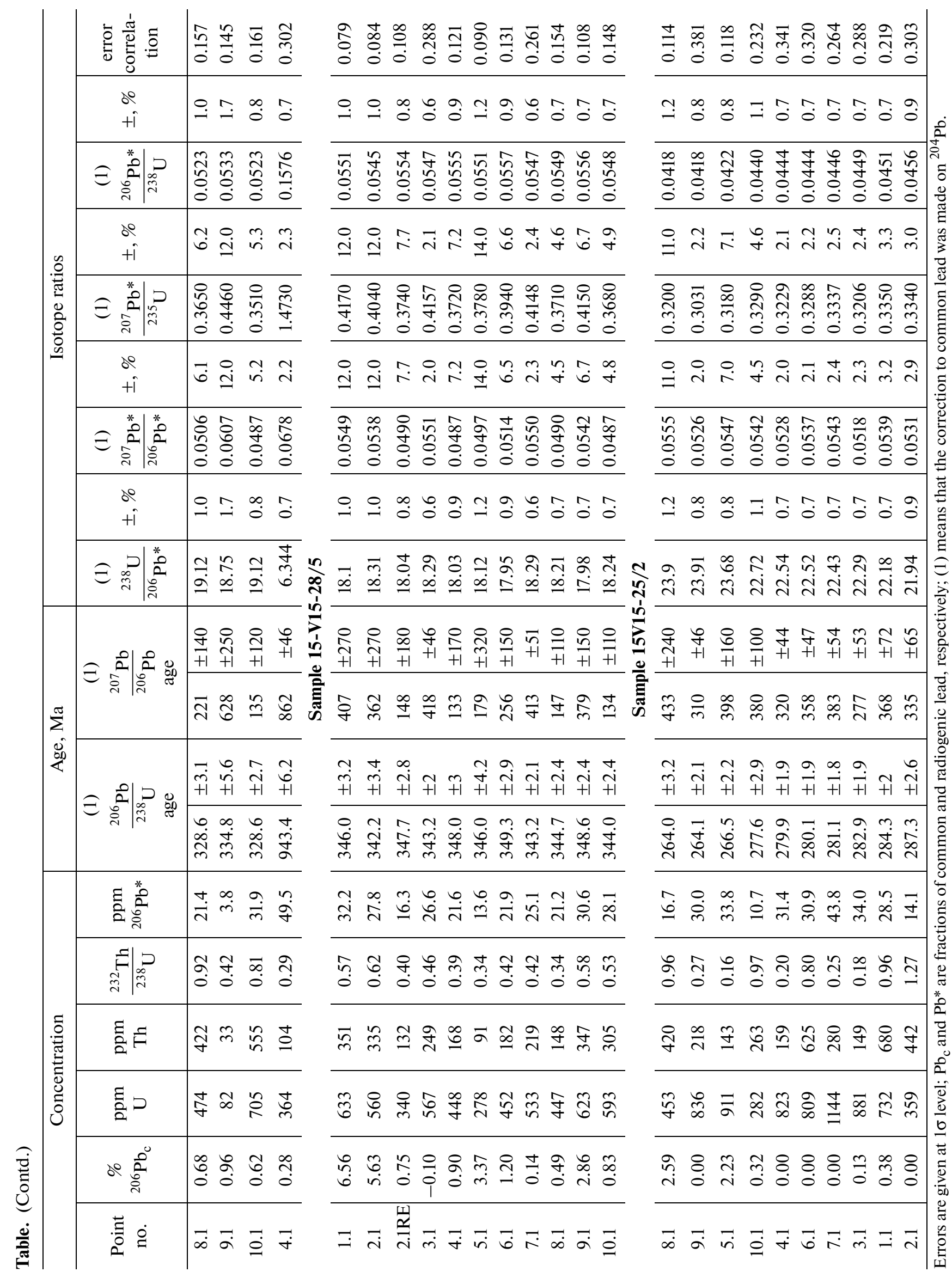



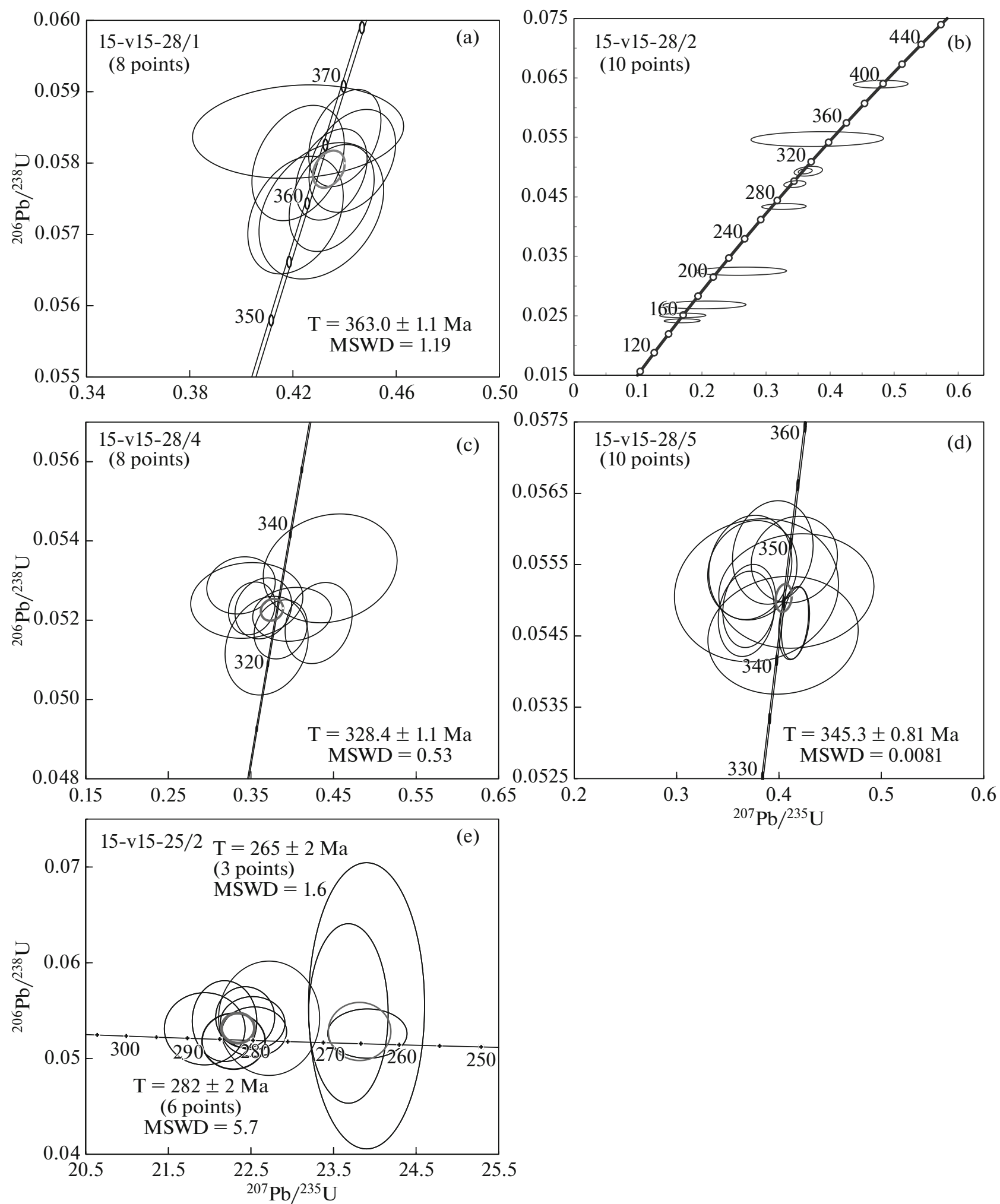

Fig. 4. Concordia diagrams for zircons from pebbles of igneous rocks of studied samples: (a) 15-v15-28/1, (b) 15-v15-28/2, (c) $15-\mathrm{v} 15-28 / 4$, (d) $15-\mathrm{v} 15-28 / 5$, (e) $15-\mathrm{v} 15-25 / 2$. 
zircon grains from this sample, the obtained concordant age was $345.3 \pm 0.81 \mathrm{Ma}$ (Fig. 4d, table).

\section{Sample 15-v15-25/2}

Pebbles of porphyraceous medium- to coarsegrained, two-feldspar biotite, cataclased granite (Fig. 3e). The sample contains yellow and brown, transparent and semitransparent, idiomorphic and subidiomorphic prismatic crystals and their fragments. Based on the dating results, several age groups of zircons were obtained. For grains 8.1, 9.1, and 5.1, the concordant age was $265 \pm 2 \mathrm{Ma}$. Crystal 10.1 was $277.6 \pm 2.9 \mathrm{Ma}$ in age $\left({ }^{206} \mathrm{~Pb} /{ }^{238} \mathrm{U}\right)$. The remaining six zircons yielded a concordant age of $282 \pm 2 \mathrm{Ma}$ (Fig. 4e). The age of granites is likely Early to Middle Permian, but the available data are insufficient for preference of any concordant ages above the others.

\section{DISCUSSION}

The studied pebbles from the Lower Jurassic sedimentary strata of Hall Island are represented by intrusive and extrusive rocks, often cataclased. Pebble sizes vary from 5 to $12 \mathrm{~cm}$, indicating a short distance of their transport and a close location of the provenance area. Based on the occurence catcalstic structures of granitoids, we assume that dynamic metamorphism was widespread in the provenance area. The ages of zircons from three out of five studied samples correspond to the end of the Late Devonian-Early Carboniferous. In sample 15-v15-25/2, concordant age clusters show the Early and Middle Permian ages. Tectonic structure of the FJL is represented by a series of horsts and narrow grabens between them (both are predominantly of NNE directions); the thickness of the Upper Paleozoic(?)-Mesozoic sedimentary cover varies from 1 to $7 \mathrm{~km}[1-3]$. The possible provenance area of the studied pebbles in the Early Jurassic could be one of these horst-shaped rises in the FJL basement.

Late Paleozoic felsic magmatism has not been reliably revealed within the northern Barents Sea. For example, on Svalbard, located west of FJL, Early Paleozoic granitoids are related to the Caledonian orogeny [13]. On the Novaya Zemlya archipelago, only Early Frasnian basic magmatism, marking a rifting event, was described [8]. In the North Svalbard Rise (north of Victoria Island located between Svalbard and FJL), dredging recovered a considerable amount of pebbles of granodiorites, two-mica and muscovite granites, and microcline gneisses. The ${ }^{40} \mathrm{Ar}-{ }^{39} \mathrm{Ar}$ isotope ages of granodiorite pebbles varied from 344 to $369 \mathrm{Ma}$. In the same area, seismoacoustic profiling conditionally identified a stock-like intrusive body and three dike-shaped uplifts [2].

Felsic magmatism is broadly manifested on southern Severnaya Zemlya and the northern Taimyr Peninsula (the Kara block). In recent years, dating of granitoids from the southern margin of the Kara block has shown the broad distribution of Early Carboniferous felsic magmatism, with subordinate Early Permian felsic magmatism $[4,9]$. Geological succession of Bolshevik Island (Severnaya Zemlya) and the northern Taimyr Peninsula is similar to that known from the borehole on FJL. For example, on Bolshevik Island, Early Cambrian metasedimentary rocks are intruded by Late Paleozoic granites and overlapped by a thin Carboniferous-Permian coal-bearing strata with a sharp angular unconformity $[4,6,12]$. This may indicate the similarity between Paleozoic geological evolutions of FJL and Kara block areas. It was supposed earlier that the Kara block was probably of peri-Baltic origin $[14,15]$. Our studies have revealed that Late Paleozoic felsic magmatism of the northern Barents Sea and the Severnaya Zemlya archipelago is coeval, indicating the similar geological evolutions of these regions during the Late Paleozoic.

\section{CONCLUSIONS}

(1) Based on $\mathrm{U}-\mathrm{Pb}$ dating of zircons from five pebble samples of felsic igneous rocks from Lower Jurassic succession of Hall Island, it has been revealed that Late Paleozoic magmatism in the northern Barents Sea had a broad distribution. Three out of five samples yielded concordant ages at $328.4 \pm 1.1,345.3 \pm 0.81$, and $363 \pm 1.1 \mathrm{Ma}$, corresponding to Late DevonianEarly Carboniferous. One sample yielded two concordant $\mathrm{U}-\mathrm{Pb}$ ages $282 \pm 2$ and $265 \pm 2 \mathrm{Ma}$, corresponding to the Early and Middle Permian. In one pebble, the data were insufficient to determine the age of the magmatic event.

(2) The obtained ages of felsic magmatism in the northern Barents Sea correlate with age of magmatism on the Severnaya Zemlya archipelago and the northern Taimyr Peninsula, indicating the similar geological evolution of these regions during the Late Paleozoic.

\section{ACKNOWLEDGMENTS}

The work was partially supported by the Russian Foundation for Basic Research (project no. 16-5520012) and by the Research Council of Norway (254962/H30).

\section{REFERENCES}

1. State Geologic Map of Russian Federation, Scale 1: 1000000 (New Series). Sheet T-37-40 (Franz Josef Land, Southern Islands), Ed. by S. I. Shkarubo (VSEGEI, St. Petersburg, 2004).

2. State Geologic Map of Russian Federation, Scale 1: 1000000 (New Series). Sheet T-37-40 (Franz Josef Land, Northern Islands). Explanatory Note, Ed. by A. A. Makar'ev (VSEGEI, St. Petersburg, 2006) [in Russian].

3. State Geologic Map of Russian Federation, Scale 1: 1000000 (Third Generation). North Kara-Barents Sea Series. Sheet U-41-44 (Franz Josef Land, Northern 
Islands). Explanatory Note, Ed. by A. A. Makar'ev (VSEGEI, St. Petersburg, 2011) [in Russian].

4. State Geologic Map of Russian Federation, Scale 1: 1000000 (Third Generation). Sheet T-45-48 (Cape Chelyuskin). Explanatory Note, Ed. by A. A. Makar'ev (VSEGEI, St. Petersburg, 2013) [in Russian].

5. I. S. Gramberg, I. V. Shkola, E. G. Bro, V. A. Shekhodanov, and A. M. Armishev, "Parametric boreholes on islands of the Barents and Kara seas," Sov. Geol., No. 1, 95-98 (1985).

6. V. B. Ershova, A. V. Prokopiev, A. K. Khudoley, G. V. Shneider, T. Andersen, K. Kullerud, A. A. Makar'ev, A. V. Maslov, and D. A. Kolchanov, "Results of U-Pb (LA-ICPMS) Dating of Detrital Zircons from Metaterrigenous Rocks of the Basement of the North Kara Basin,” Dokl. Earth Sci. 464, 9971000 (2015).

7. A. A. Kaplan, P. Copeland, E. G. Bro, E. A. Korago, V. F. Proskurin, N. A. Vinogradov, and P. J. Vrojlijk, "New radiometric ages of igneous and metamorphic rocks from the Russian Arctic," in Abstracts of AAPG Regional Conference, St. Petersburg, 2001 (VNIGRI, St. Petersburg, 2001), p. 6.

8. E. A. Corago and T. N. Timofeeva, Magmatism of the Novaya Zemlya in the Context of Geological Evolution of the Barents-North Kara Region (VNIIOkeangeologiya, St. Petersburg, 2005) [in Russian].

9. A. A. Makar'ev and E. M. Makar'eva, "New data on ages of particular geologic units on islands and coast of the eastern Kara Sea," Razved. Okhrana Nedr, No. 8, 71-77 (2012).

10. N. M. Stolbov, N. V. Ustinov, and E. Yu. Golubkova, "Which age are deposits in the folded basement of the Franz Josef Land?," in Gelogical-Geophysical Characteristics of the Arctic Region Lithosphere, Vol. 210 of Tr. NIIGA-VNIIOkeangeologiya (VNIIOkeangeologiya, St. Petersburg, 2006), No. 6, pp. 145-148.

11. L. P. Black, S. L. Kamo, C. M. Allen, J. N. Heinikoff, D. W. Davis, J. Russel, R. J. Korsch, and C. Foudonlis,
"TEMORA 1: A new zircon standard for $\mathrm{U}-\mathrm{Pb}$ geochronology," Chem. Geol. 200, 155-170 (2003).

12. V. B. Ershova, A. V. Prokopiev, V. A. Nikishin, A. K. Khudoley, A. M. Nikishin, and N. A. Malyshev, "New data on Upper Carboniferous Lower Permian deposits of Bol'shevik Island, Severnaya Zemlya Archipelago," Polar Res. 34, Pap. No. 24558 (2015). doi 10.3402/polar.v34.24558

13. D. G. Gee, H. Fossen, N. Henriksen, and A. K. Higgins, "From the Early Paleozoic platforms of Baltica and Laurentia to the Caledonide Orogen of Scandinavia and Greenland," Episodes 31, 44-51 (2008).

14. H. Lorenz, D. G. Gee, and A. Simonetti, "Detrital zircon ages and provenance of the Late Neoproterozoic and Palaeozoic successions on Severnaya Zemlya, Kara Shelf: A tie to Baltica," Norw. J. Geol. 88, 235-258 (2008).

15. H. Lorenz, P. Männik, D. Gee, and V. Proskurnin, "Geology of the Severnaya Zemlya Archipelago and the North Kara Terrane in the Russian high Arctic," Int. J. Earth Sci. 97, 519-547 (2008).

16. K. R. Ludwig, SQUID 1.02. A User's Manual; Berkeley Geochronol. Center Spec. Publ. No. 2 (Berkeley, Calif., 2001).

17. K. R. Ludwig, ISOPLOT 3.00. A User's Manual; Berkeley Geochronol. Center Spec. Publ. No. 4 (Berkeley, Calif., 2003).

18. V. Pease, D. Gee, and B. Lopatin, "Is Franz Josef Land affected by Caledonian deformation?," in Eur. Union Geosci. XI Conference Abstr. (2001), p. 757.

19. I. S. Williams, "U-Th-Pb geochronology by ion microprobe: Applications of microanalytical techniques to understanding mineralizing processes," Rev. Econ. Geol. 7, 1-35 (1998).

Reviewer: T.N. Kheraskova

Translated by N. Astafiev 